\title{
One Door Integrated Service Bureaucracy Known as (PTSP) in Indonesia
}

\author{
Ngalimun; Sri Suwitri; Hardi Warsono; Kismartini \\ Public Administration Doctoral Program, Faculty of Social and Political Science, \\ Diponegoro University \\ Semarang, Indonesia \\ (Office Email: prodidap@gmail.com)
}

\begin{abstract}
Integrated Service reform one door (PTSP) is to improve public services quality preceded by a changing of bureaucracy paradigm that is clean and serve. PTSP arranged in presidential regulation Number 97 in 2014 about One Door Integrated Service management. Regulation of the Minister of State for Administrative Reform and the Bureaucracy Reform No 36 in 2012 is about Technical Drafting Instructions standard service. Regulation of the Minister of State for Administrative Reform and Bureaucracy Reform number: PER URM.PAN//15/7/2008 about the of Bureaucracy Reform guidelines. The Bureaucracy Reform at the Ministry in order to cut the chains of bureaucracy where services are scattered throughout a work Unit Area (SKPD) into PTSP. One door Integrated Services (PTSP), in licensing service impact on multi effect with ease minding permission, many investors comes to Indonesia can absorb the workforce and increasing taxes.
\end{abstract}

Keywords-Integrated Service; PTSP and One Door

\section{INTRODUCTION}

One Door Integrated Services (PTSP), bureaucratic reform in this era that needs to be addressed by public service application, it is an activities series in the framework of the fulfillment of the service necessity accordance with the regulations for each citizen and resident of goods, services and administrative services provided by the public service organizer, accordance with Act No. 25 in 2009 about public service. In article 9 paragraph (2) the arrangements concerning the integrated service system one door. Government Regulation Number 96 in 2012 about the directions of the implementation of Act No. 25 of 2009 about public service.

Accordance with Act No. 17 in 2007, about the Long-term National Development Plan 2005-2025 and the regulation of the Minister of State, Bureaucratic Reform and PAN number: PER URM.PAN//15/7/2008 about the Bureaucracy Reform guidelines. The Regulation of the Minister of PAN and Bureaucracy Reform declare in Number 20 in 2010 about Bureaucratic Reform Road Map 2010-2014. Bureaucratic Reform Road Map (RMRB) aims to provide the implementation direction of the bureaucracy reform at the Ministry/Agency $(\mathrm{K} / \mathrm{L})$ and local government in order to run effectively, efficient, scalable, consistent, integrated, sustainable, and work continue.

\section{A. Issues of Government Bureaucracy Reform}

Bureaucratic reform has to start from the institutional and human resources apparatus arrangement. Next is making arrangements, mechanisms, systems, and procedures are not simple convoluted, enforce accountability apparatus, improving and creating a comprehensive oversight, and improving public services quality towards those qualities and excellence. Bureaucratic reform need to be prioritized in the public service work units such as service permissions. Presidential regulation number 97 in 2014 is about One Door Integrated Service management. Licensing services part of the Government functions as the fulfillment community necessity as a consumer (the products of Government), will be the Ministry of public service and civil, faced with many problems especially relates to Bureaucratic Reform demands of the various parties concerned.

The Ministry of the PAN has been analyzing into the reform of government bureaucracy and identifying trees thoughts Bureaucratic Reform State Apparatus (Youth Program Field study in 2003-2004) described as follows:

1) Institutional: the structure of lean and rich functionality, streamlined, and effectively.

2) Human Resources Reform: human resources professional, neutral, and prosperous, modern staffing management, neutral, prosperous, useful, effective, productive, transparent, clean and free of $\mathrm{CCN}$ to serve and society empower.

3) Governance or Management: performance simplified Government apparatus, characterized by the mechanism, system, procedure, and the work is orderly, efficient, and effective.

Thus some legislation has been established as terms of local governments reference organization, the difficulties faced are:

1) Integrated Service bureaucracy Reform one door (PTSP) which has the dimensions of wide, so many interrelated aspects and requires the intervention and coordination between the various parties concerned;

2) Authority Devolution service permissions that have not been accordance with the licensing arrangements where expectations are still some SEGWAY. 
3) Bureaucratic Reform is not yet available in a quick, precise and accurate, but the availability of such information is a top priority (entry point) to improve the performance of the bureaucracy towards professional and accountable.

4) Institutional PTSP/SEGWAY in diverse Indonesia resulting in increased the problem complexity.

There are many problems of policy issues which cast doubt on the bureaucracy reform theory (Paudel, 2009), the weak regulatory condition. Bureaucracy implementation use inconsistent implementation, the concept is often used to classify characters as well as the implementation process outputs also outcome from the implementation in the service permissions granting.

\section{TheOreticAl FramewOrK AND Method}

Background issue of Integrated Services on One Door is still in complaining about society because the Ministry is still Working Units spread across several Devices area (SKPD), not all permissions transferring to the PTSP. It is still going attraction authority permissions, and doesn't take permission. It is considered the original revenue source known as (PAD) of this Region.

\section{RESUlT AND DiscUSSION}

Bases on the discussion results and explanation that the provincial Government/County/City in Indonesia in the Bureaucracy Reform One Door Integrated Services (PTSP) can be seen to the institutional organization of the PTSP there head office and head of the Agency as well as the head of Department. In doing the bureaucracy reform to improve the public service quality is preceded by the changing of bureaucracy paradigm that is clean and serves, and improving then human resources quality through the preparation of Apparatus standard human resources competencies reform public service providers. Human resources competence Apparatus which is the accumulation of education/training variable level, the number of working experience years and service variety is the determining of public service quality. As the increase in public services quality, then human resources reform mindsets need to be tailored to this paradigm.

Institutional PTSP synchronization to the attention of the (reform) the procedure to be done comprehensively and coordinative, hence the sectors and agencies that have the authority relates to the application of compulsory procedures make improvements in order to achieve the objectives of Bureaucracy Service Reform seen from the normative point of view as authority to move, harmonize, align, so that everything is focused on achieving a specific purpose at this time. From a functional point of view, the coordination is done in order to reduce the potential negative impact specialization, and streamline the Division of labor in organizations associate the day-to-day adjustment, the achievement process of a purpose among the goals are tied to it.

SOP as guidelines are binding on the various activities or relates items in the dimension of time, place, cost components, function, and significance, an organizer of the PTSP with user community services, so that both parties are focused on
Government single goal set and success is not tainted by the other party. More Ndhara (1989:41) suggests that coordinating means to own on the initiative of informing the things that need to be looked at through a communication medium available, so the deal and alignment as well as harmony. The bureaucracy is one of the institutions most often even as a whole become activity executor. Even in certain cases the bureaucracy is created just to run a certain policy. Ripley and Franklin in Winarno (2005:145-160) identified six characteristics of a bureaucracy as a result of bureaucracy observation in the United States, as follows: Bureaucracy is not the power of neutral and not in full control of outside parties; Bureaucracy is created as an instrument in addressing public needs purposes (public affair); Bureaucracy is the dominant institution in public bureaucracy reform has different interests in any hierarchy; Bureaucracy has a number of different purposes; The function of bureaucracy are in a complex environment and wide; Bureaucracy has a high survival instincts so rarely found a bureaucracy of death. Upon the explanation above, then understand the bureaucratic structure is the fundamental factor to examine public bureaucracy reformation. According to Edwards III Winarno (2005:150) there are two main characteristics of bureaucracy: "Standard Operational Procedure (SOP) and fragmentation".

\section{CONCLUSION}

Bases on the discussion and explanation results there is a conclusion that the Government of the province/district/city in Indonesia in the bureaucracy reform of One Door Integrated Services (PTSP) can analyze strengthening Institutional Organization in order to stimulating permission and non service permissions in transferring to PTSP. The bureaucracy reform is still facing obstacles PTSP associated with authority transferring that the licensing service is not yet everything transferring to PTSP but some still on by SEGWAY. Integrated service quality improvement in One Door in Indonesia especially institutional strengthening recommendation policy direction PTSP bureaucratic reform program to encourage in order to be achieved to attract investors in Indonesia, the need for: "The institutional organization of the Synchronization in head Agency form" in the continued policy implementation, with the original Fist PTSP institutional Office become the Agency head, it is in order for the coordination with the SEGWAY technical running synergy to the application against improvements (reform).

Integrated Service of One Door is a bridge in the improving service quality, with given the ease in taking care of Permits then it will have an impact on investors' entry into Indonesia, with many companies go in then it could absorb the workforce and have an impact on increasing tax. The realization of strengthening government bureaucracy in order to a Government that is clean and free of $\mathrm{CCN}$, increasing the public services quality to society, and increasing the capacity and accountability of the bureaucracy performance. 


\section{REFERENCES}

[1] Asian Journal of Social Sciences \& Humanities Vol. 4(4) November 2015. Jurnal Implementation Policy Integrated Service (Oss) In South Sumatra Province

[2] Edwards III, George C 1980. Implementing Public Policy Washington DC: Congresional Quarterty Press.

[3] Mustopadidjaja, AR, 2007, Manajemen Proses Kebijakan Publik, Formulasi, Implementasi dan evaluasi Kinerja, LAN (Lembaga Administrasi Negara

[4] Menuju Manajemen Publik Kelas dunia, Formulasi Reformasi Birokrasi di Indonesia (secretariat Komite Pengarah Reformasi birokrasi Nasional , 2012).

[5] Ndraha, Taliziduhu. Kybernology (Ilmu Pemerintahan Baru) 1 \& 2, Rineka Cipta, cetakan pertama, Mei 2003.
[6] Paudel, Narendra Raj. A Critical Account of Policy Implementation Theories: Status and Reconcideration Nepalese Journal of Publik Policy and Governance, Vol XXV, No 2 December 2009

[7] Winarno, Budi, 2002. Teori dan Proses Kebijakan Publik. Yogyakarta: Media Presindo.

[8] UU 25 Tahun 2009 tentang Pelayanan Publik.

[9] PP Nomor 96 Tahun 2012 tentang Pelaksanaan UU 25 Tahun 2012 Pelayanan Publik.

[10] Peraturan Presiden Nomor 97 Tahun 2014 Tentang Pelayanan Terpadu Satu Pintu.

[11] Peraturan Menteri PAN dan RB. Nomor: 15/M.PAN/7/2008 tentang Pedoman Umum Reformasi Birokrasi.

[12] Peraturan Menteri PAN dan RB. NOMOR 20 TAHUN 2010 Tentang Road Map Reformasi Birokrasi 2010-2014 